\title{
A GIS-based multi-criteria decision analysis approach for public school site selection in Surabaya, Indonesia
}

\author{
Daniel Hary Prasetyo, Jamilah Mohamad, and Rosmadi Fauzi
}

\begin{abstract}
Surabaya is one of the old cities of Indonesia and has been inhabited since the Colonial era. It has been continuously growing until today leading to expansion of its area to the south, east, and west. Unfortunately, it has not been supported by the addition of new public schools, particularly at the secondary and high school levels. This research aimed to help the government by determining the suitability level of the whole area of the city for locating a new school and for evaluating current school locations. This research proposed six spatial factors: administration, population, transportation, land-use, student flow, and public preferences. Each factor was represented as raster file built from primary and secondary tabular and spatial data. Each factor then was weighted from the multicriteria decision analysis step using the analytical hierarchy process method. The results show recommended and non-recommended areas in Surabaya for locating a new school building. This research integrated GIS analysis, web-GIS application, public participation, and MCDA to identify the best solution for this case.

Key words: GIS analysis, MCDA, AHP, F-AHP, school, local government.

Résumé : Surabaya est une des anciennes de l’Indonésie habitée depuis l'époque coloniale. Elle continue de s'étendre continuellement jusqu'à maintenant menant à l'expansion de ses zones au sud, à l'est et à l'ouest. Malheureusement, elle n'a pas été soutenue par l'ajout de nouvelles écoles publiques, particulièrement pour les niveaux secondaires et postsecondaires. La recherche visait à aider le gouvernement à déterminer le caractère adéquat de l'ensemble de la ville pour bâtir une nouvelle école et à évaluer les emplacements actuels des écoles. Cette recherche a fait appel à six facteurs spatiaux : l'administration, la population, le transport, l'aménagement des terres, le flux d'élèves et les préférences publiques. Chaque facteur a été représenté comme fichier raster bâti à partir des données tabulaires primaires et secondaires et des données spatiales. Chaque facteur a ensuite été pondéré de l'étape d'analyse décisionnelle multicritères à l'aide de la méthode de hiérarchie multicritères. Le résultat illustre les zones recommandées et non recommandées à Surabaya pour y situer un nouveau bâtiment d'école. La recherche a intégré l'analyse SIB, l'application SIG web, la participation publique et les RMPC pour identifier la meilleure solution pour cette situation. [Traduit par la Rédaction]
\end{abstract}

Mots-clés : analyse SIG, RMPC, MHM, MHM-F, école, gouvernement local.

Received 4 July 2018. Accepted 5 November 2018.

D.H. Prasetyo. University of Surabaya, Surabaya, Indonesia; University of Malaya, Kuala Lumpur, Malaysia. J. Mohamad and R. Fauzi. University of Surabaya, Surabaya, Indonesia.

Corresponding author: Daniel H. Prasetyo (email: daniel@staff.ubaya.ac.id).

Copyright remains with the author(s) or their institution(s). Permission for reuse (free in most cases) can be obtained from RightsLink. 


\section{Introduction}

Surabaya is at $07^{\circ} 21^{\prime}$ south latitude and from $112^{\circ} 36^{\prime}$ to $112^{\circ} 54^{\prime}$ east longitude. It is the second largest city in Indonesia with an area of $33306 \mathrm{~km}^{2}$. There are more than 3 million residents spread across 31 districts and 163 sub-districts. Based on the data recorded by the Civil Department at the end of 2013, the population of Surabaya residents (who are registered in the family card) was 3183233 consisting of 934983 families. Surabaya is among the largest educational sector focused cities in Indonesia, as suggested by its education budget that exceeds 30\%. There are 1622 schools at the elementary level, consisting of 564 public and 1058 private schools. At the secondary level, there are 42 public schools and 300 private schools for a total of 342 schools. At the high school level, there are 257 schools; 33 schools are public and 224 schools are private. Surabaya has 492495 school-aged citizens. There are 270076 citizens of elementary school age, 114733 citizens of secondary school age, and 107686 citizens of high school age. All public schools are managed by the Educational Department of Surabaya. Figure 1 shows the public schools at the primary level, secondary level, and high school level along with the populated area and district boundaries.

With a growth of $1.2 \%$ per year, Surabaya's populated area has developed to the south, east, and west. This growth in population has not been followed by new public school development, particularly at the secondary and high school levels. As a consequence, currently, the public school service cannot be equally accessed by citizens, as secondary schools and high schools are not equally distributed over the area of the city.

This research aimed to develop a model that can be used by the government to determine which areas in Surabaya are suitable to build new secondary schools and (or) high schools. In addition, it determined primary schools that are more suitable for being upgraded to a secondary school. The output is a spatial layer that covers the whole area of Surabaya, including values that indicate the suitability previously described.

Since the 1990s, multi-criteria decision analysis (MCDA) and geographic information systems (GIS) have been used together as powerful tools to solve some spatial problems in urban planning because of their ability to identify a location using complex criteria. Research regarding land suitability, land use planning, site selection, and disaster mitigation has been widely conducted using GIS-based MCDA. Romano et al. (2015), Bozdağ et al. (2016), and Yalew et al. (2016) utilized GIS-based MCDA for assessing the suitability of land for agriculture. After applying the analytical hierarchy process (AHP), weighted linear combination (WLC), and ordered weighted averaging (OWA) in their study, Romano et al. (2015) suggested involving the public in the planning process. Grêt-Regamey et al. (2017) developed an interactive and scenario-based GIS-based MCDA termed potential allocation of urban development areas for sustainable land management (PALM).

Bozdağ et al. (2016) used the AHP to calculate the relative importance value of soil, climate, topography, and groundwater characteristics. The result indicated suitable land for sustainable agriculture. Yalew et al. (2016) proposed the application of data from Google Earth, processed using QGIS and a web-based AHP application, whereas Shokati et al. (2016) created a web-based GIS MCDA model. These methods have been implemented in some plantations, e.g., mango (Elsheikh et al. 2015), Arabica coffee (Nzeyimana et al. 2014), and cork oak plant (Bagaram et al. 2016).

Furthermore, assessments of urban land-use suitability and land-use planning using the GIS-based MCDA method have been conducted by Nguyen et al. (2015) and Mosadeghi et al. (2015). In addition, Mosadeghi et al. (2015) compared MCDA with the AHP method and Fuzzy AHP method.

GIS-based MCDA combined with several factors of an optimal location was used to find an optimal industrial site (Rikalovic et al. 2014), selecting some parking sites 
Figure 1. Distribution of public schools. [Colour online.]

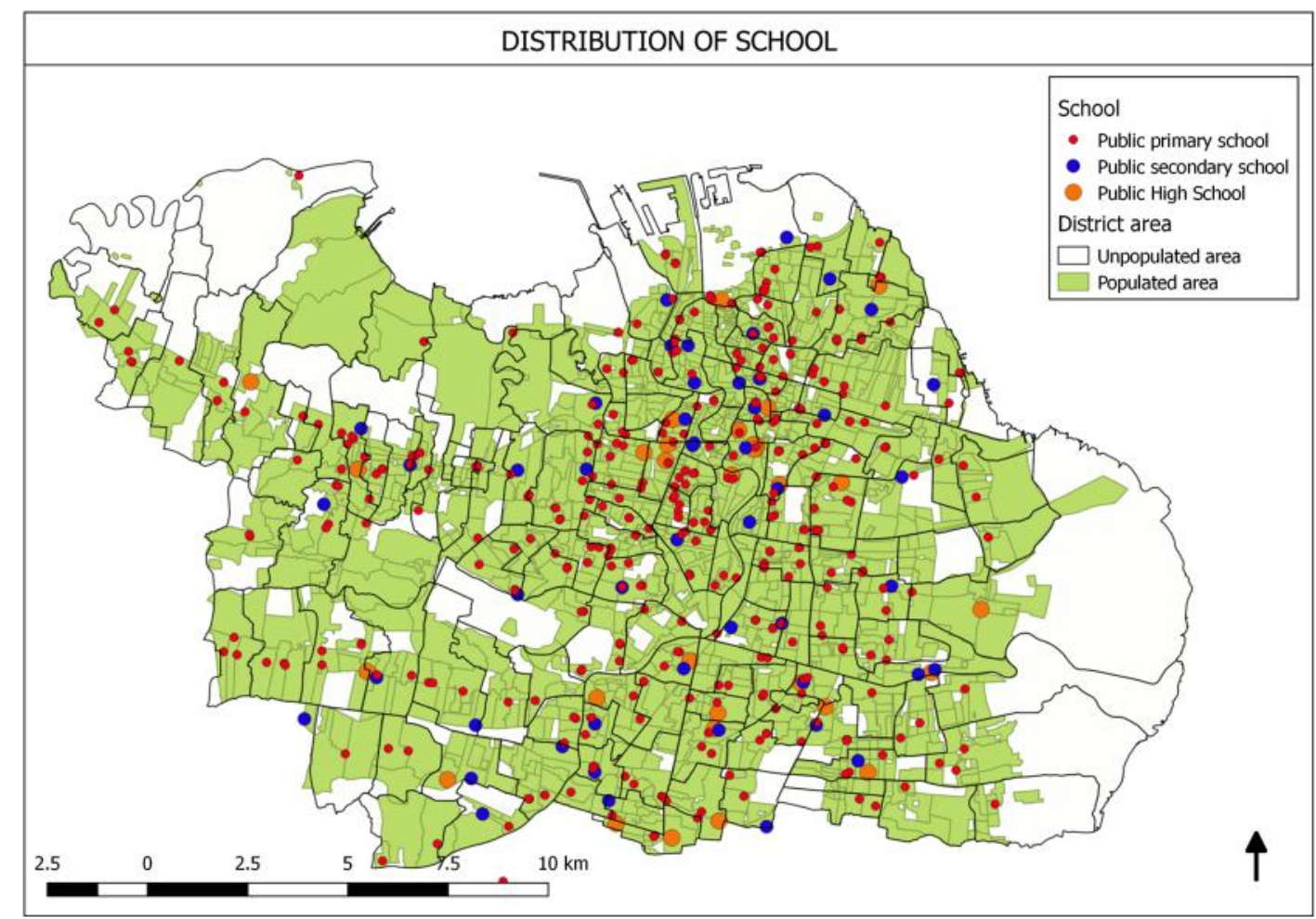

(Jelokhani-Niaraki and Malczewski 2015), and for siting a nuclear power plant (Abudeif et al. 2015). Furthermore, Abudeif et al. (2015) used the WLC and AHP methods to screen and select potential sites in an ArcGIS 10.1 environment. Sustainable landfill sites were successfully found using the MACBETH method (Demesouka et al. 2016) and AHP method (Aksoy and San 2017). In addition, the AHP method was also used to identify a thermal power plant site (Siefi et al. 2017), solar power potential locations (Aly et al. 2017), offshore wind and wave energy sites (Vasileiou et al. 2017), and transmission tower locations (Veronesi et al. 2017).

Studies that used GIS-based MCDA to find an optimal site for a wind farm were conducted by Szurek et al. (2014), Atici et al. (2015), Latinopoulos and Kechagia (2015), Watson and Hudson (2015), Noorollahi et al. (2016), and Anwarzai and Nagasaka (2017). However, Szurek et al. (2014), Latinopoulos and Kechagia (2015), and Watson and Hudson (2015) used AHP and WLC methods to determine weights of siting criteria and to develop a composite suitability map.

Several researchers have used GIS-based MCDA for disaster mapping, e.g., flood and risk management and mitigation (Papaioannou et al. 2015; Xiao et al. 2016; Fernandez et al. 2016; Rahmati et al. 2016; Pourghasemi et al. 2014, Dragićević et al. 2015), landslide susceptibility mapping (Erener et al. 2016), and land subsidence level prediction (Ghorbanzadeh et al. 2018). Apaioannou et al. (2015) compared their MCDA results using the AHP and Fuzzy AHP method, whereas other researchers only used the AHP method.

Groundwater is also an interesting study object for several researchers. Using GIS-based MCDA, Sahoo et al. (2015) and Saidi et al. (2017) explored groundwater prospects, Esquivel et al. (2015) and Singh and Katpatal (2017) identified groundwater resources to prioritize 
Figure 2. Methodology schema of the study.

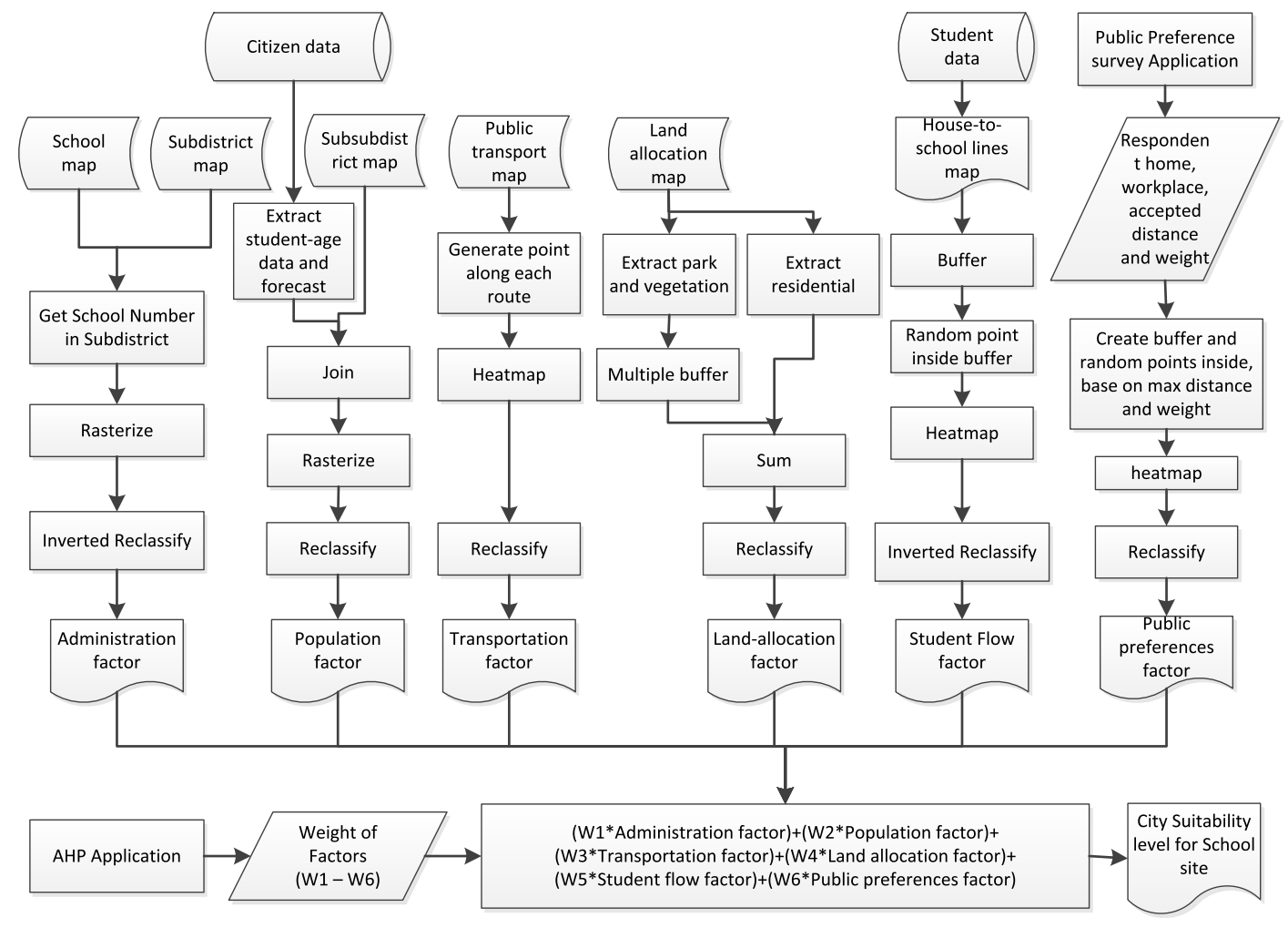

in monitoring, and Capilla et al. (2016) sought an optimal reservoir location. These last three researchers used the AHP method.

Based on the aforementioned successful GIS-based MCDA research and considering the characteristics of the current research problem, this study used a GIS-based MCDA method to find the optimal area for locating a new public school. This research used classical AHP and Fuzzy AHP (F-AHP) methods to minimize the participant subjectivity (Srichetta and Thurachon 2012; Ayhan 2013; Papaioannou et al. 2015). A comparison of the result from the classical AHP and the F-AHP methods was completed.

This paper is closely related to two of the author's earlier papers. The factor investigated in this study was taken from a public preference factor identified using web-GIS application in the first paper (Prasetyo et al. 2016a, 2016b), and the use of the web-GIS application for collecting AHP judgements was based on another research study conducted in the same year (Prasetyo et al. 2016a, 2016b).

\section{Methodology}

There are two processes in this study. The first is to define the criteria that affect school location suitability, and the second is the process to judge the importance of each criteria. GIS spatial operations and analysis are the main tools that were used to process the criteria from raw data to the MCDA factors. Another tool was a web-based GIS application that facilitates participation and computes the result of the MCDA used for spatial analysis. Figure 2 shows the schema of the research methodology. 
Figure 3. Administration factor. [Colour online.]

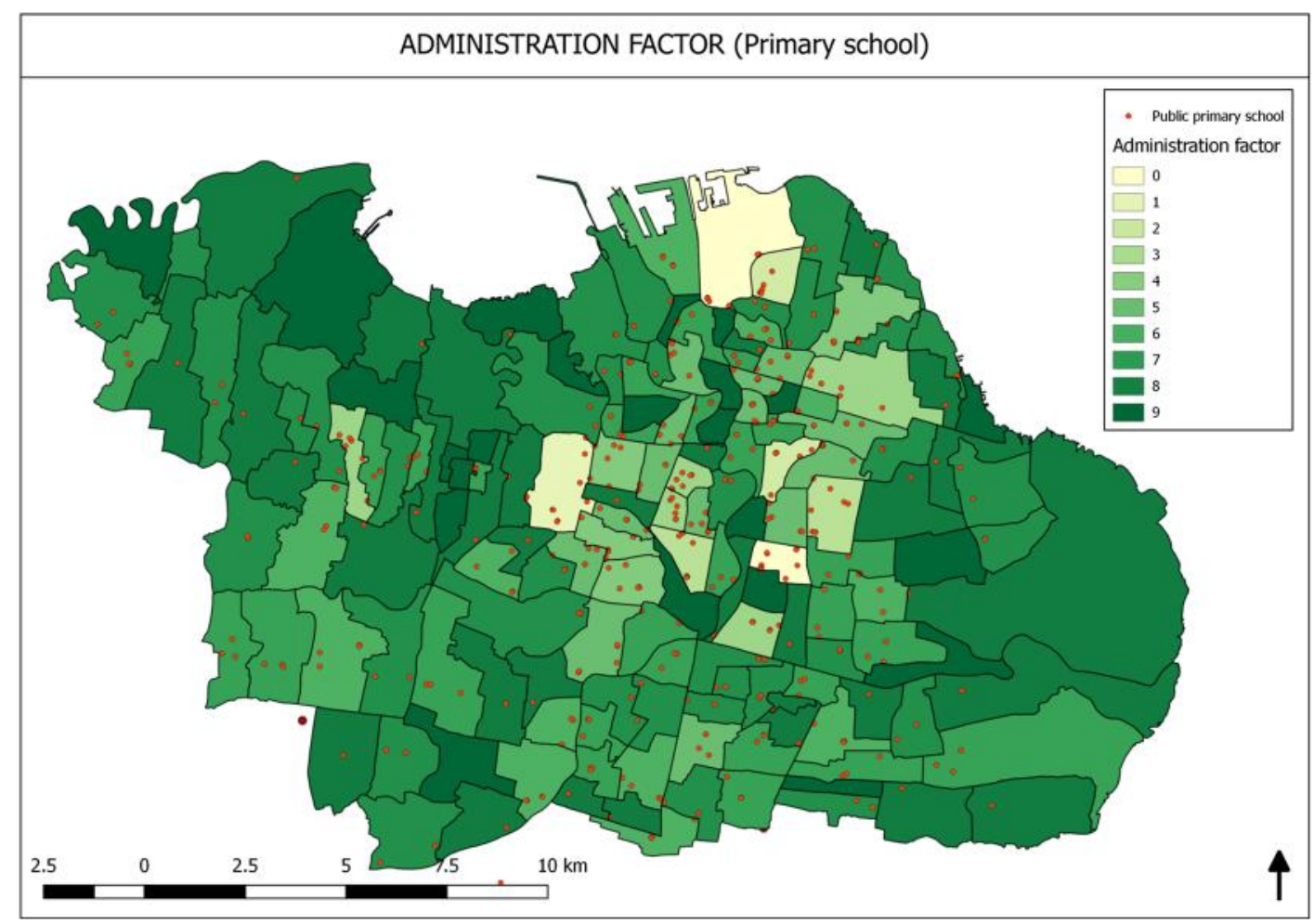

There are six different processes that produce six factors during the MCDA process. The factors are as follows: administration, population, transportation, student flow, land allocation, and public preferences. Once these factors were preprocessed, the weight of each factor was determined. This research used the AHP and F-AHP methods. The pairwise comparison was completed using an online web-GIS application to obtain more proactive and better participatory results (Saaty and Shang 2007).

Each factor was in the form of a raster layer that had a range of values to indicate the factor's suitability level. The range was from 0 to 9; a value of 0 indicated that the area was not very suitable, whereas a value of 9 indicated that the area was very suitable. For the population factor, for example, an area that was indicated as very suitable was an area with the highest population density and that area would have raster cells with a value equal to 9 . The next section will explain the factors in more detail.

\subsection{Administration factor}

District and sub-district governments are the representations of city government serving the citizen. The equal distribution of schools in a district means that an equal portion of the responsibility of the education aspect is addressed by the government at the district level. This administration factor seeks this equality. A district with a few schools or no school will receive a high value of suitability, whereas a district that already has many schools will receive a low value. This factor was developed by joining a school map and a sub-district map to generate a sub-district map with the number of school locations. This field was then used during the reclassification process to obtain the administration factor raster. Figure 3 shows the administration factor. 
Figure 4. Population factor. [Colour online.]

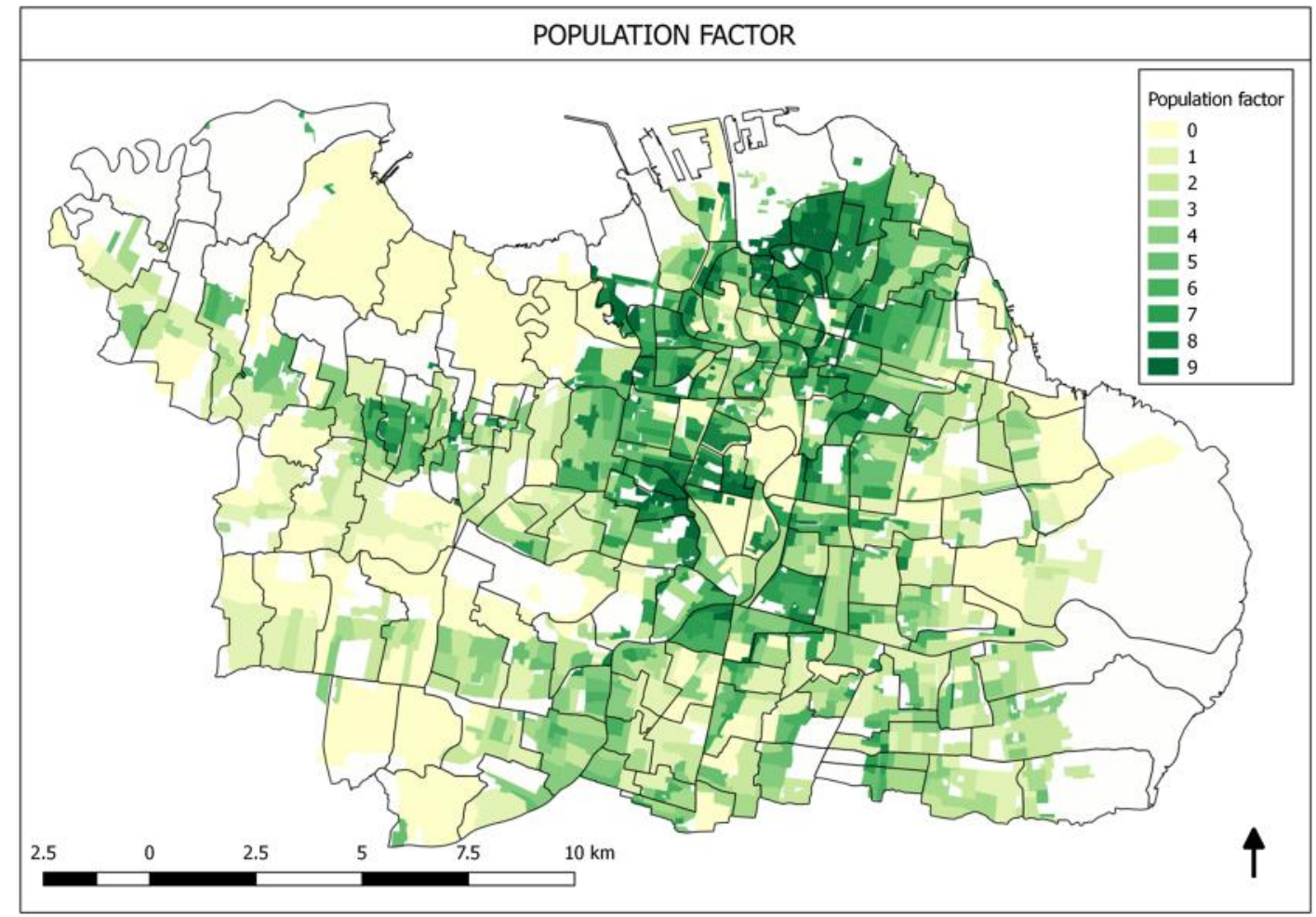

\subsection{Population factor}

The regulation of the Minister of Education Number 23 of 2013 says that the farthest distance between the location of a school and a residential area is $3 \mathrm{~km}$ for a primary level and $6 \mathrm{~km}$ for a secondary level. The population factor supports this regulation by determining which location is surrounded by a large number of potential school-age citizens. The higher the number of school-age citizens per cell, the larger the raster value. This factor was built from 3 years of citizen data and forecasted for the next 20 years using the linear forecast function in Microsoft Excel. These tabular data were extracted to obtain the number of school-age citizens per sub-sub-district before joining them with a sub-sub-district map, where they were rastered and reclassified to obtain values ranging from 0 to 9 . Figure 4 shows the population factor.

\subsection{Transportation factor}

This factor determines areas with a number of public transportation facilities surrounding them. An area with a higher number of public transportation service routes will have a higher raster value than one with fewer routes. Every available public transportation route will add an advantage to the area along the route. Surabaya has two main public transportation services: Lyn and bus. Lyn is a modified station wagon car. There were 56 Lyn routes and 14 bus routes. These routes have not changed for more than 10 years and are based on the stagnancy of road development in Surabaya. This research assumes there will not be many changes for the next 10-15 years. Every route would add an advantage to the area along it and the more routes that an area has, the better it would be. For this type of situation, a heat map approach is more suitable than a buffer approach. All transportation 
Figure 5. Transportation factor. [Colour online.]

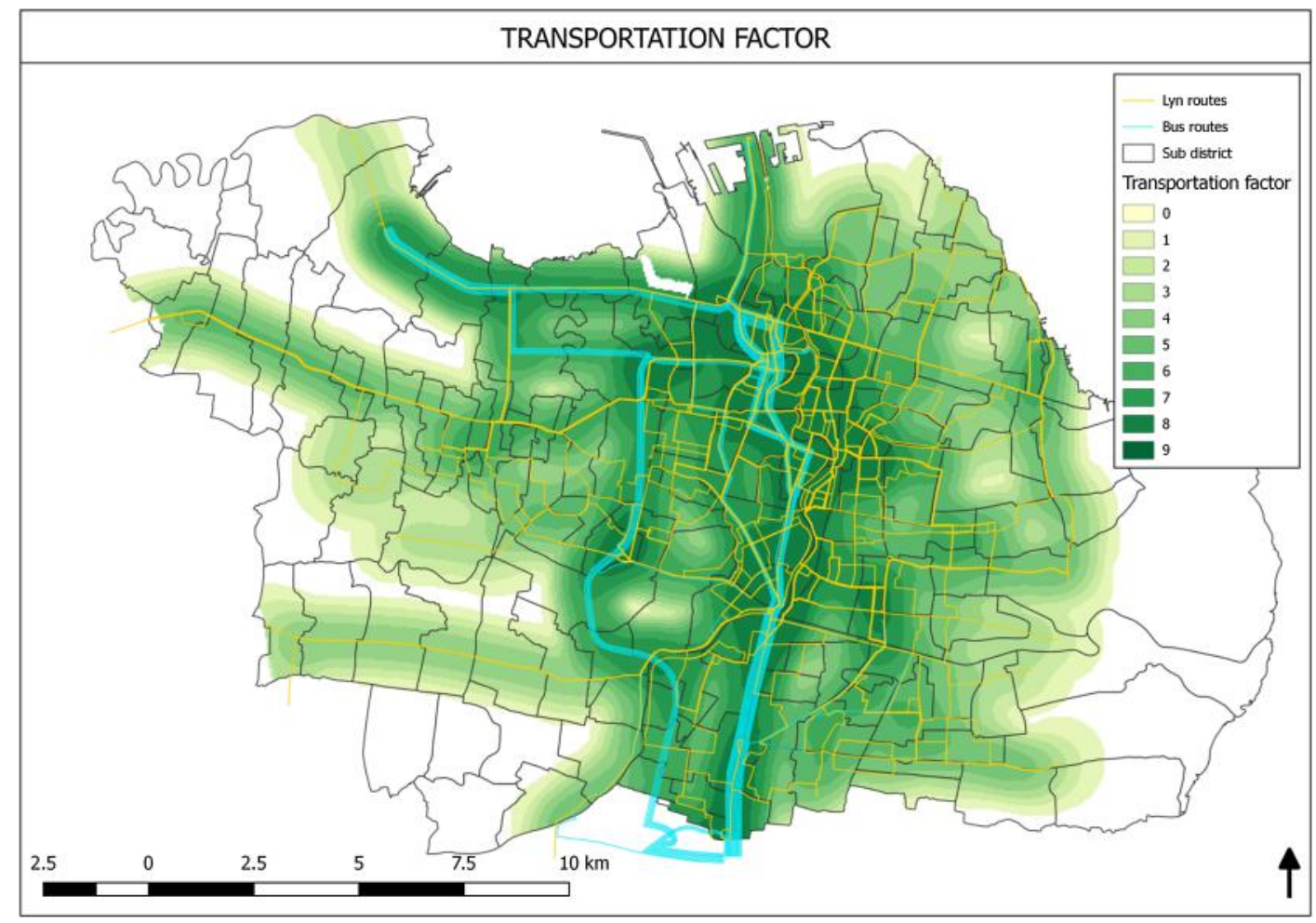

routes were used to generate transportation route points. These points were used to create a heat map and reclassify it to obtain a raster with a certain value. Figure 5 shows the transportation factor.

\subsection{Land allocation factor}

The fourth factor is land allocation. This factor aims to ensure that the school location is compatible with the land use planning of the city. Schools must be in residential areas and near parks and green spaces to support sports and outdoor activities. This factor is based on the city's land allocation planning map from the city spatial planning department. This land allocation map was extracted to a residential area map and vegetation area map. The residential area was converted to a raster with a maximum point value. The vegetation area map was used for determining which areas are near and which areas are far from parks or green spaces. The accepted distance for children to walk from their school to parks to engage in an outdoor activity was assumed to be $1 \mathrm{~km}$. Ten buffer rings of $100 \mathrm{~m}$ distance were generated. The closest ring has the maximum point and it gradually decreases until its farthest point. These two layers were then summed up and reclassified. Figure 6 shows this land allocation factor.

\subsection{Student flow factor}

The fifth factor is student flow. The further the distance between the school and students' houses, the longer the time in which students crowd the streets. This factor restricts the new school location and seeks to place the school location on streets with a low density of users to divide the rush. The tabular data of students in the city obtained from the educational department was linked with spatial residential data obtained from the Demographic 
Figure 6. Land allocation factor. [Colour online.]

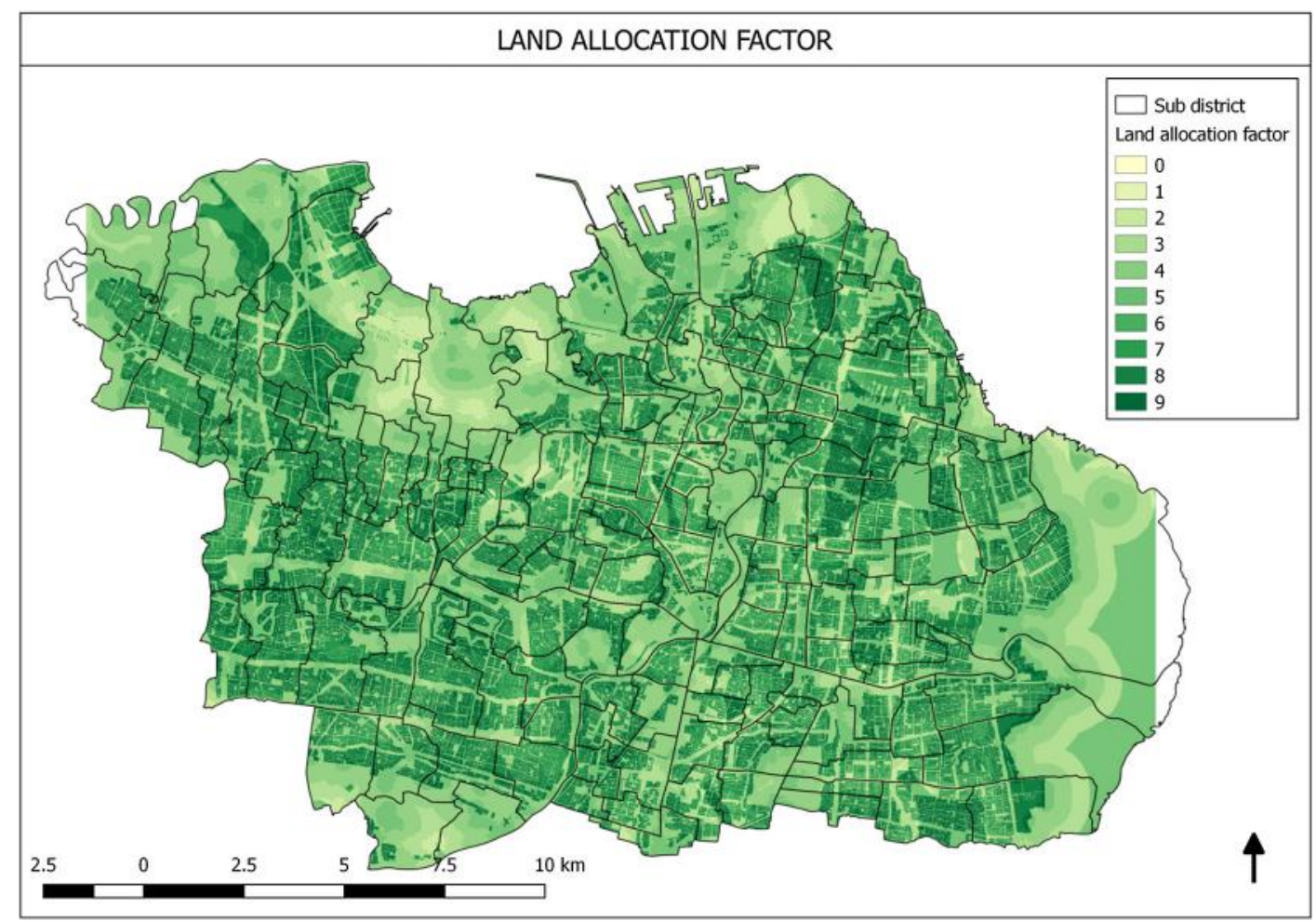

Affairs department to determine the sub-districts where students' houses and schools occur. The sub-district was taken as the basis because there were no spatial data per house available. Then, lines illustrating the students' movements were created.

These flow lines were then transformed into points to create a heat map reflecting the possible routes to be chosen by students, the number of students using the routes, and the time spent during the trip. The points representing these aspects were in a random position and spread along the area from sub-district to school. The area along the line was formed from buffers from the line to a fixed distance. This area represented the possible routes to school. The random points represented the student who travelled. The number of random points was the multiplication of a constant variable, line length, and the number of students in the flow line. The constant variable was the number that could keep the random points filling the buffer area. These points were used to create the heat map. Figure 7 shows the illustration of this process for a school. Figure $7 a$ shows the flow lines and Fig. $7 b$ shows the heat map. This process was conducted for all schools and continued with reclassification to obtain a student flow factor map, as in Fig. 8.

\subsection{Public preferences factor}

The last factor is public preference. There were two involved steps to determine this factor. The first step was collecting public opinion and the second step was analyzing the collected data. This study created a web-based application that implemented the participatory GIS concept. The application not only collected the user preferences, but also helped them in deciding upon current schools that are suitable for their criteria. This application determined the following: 
Figure 7. (a) Home to school flow lines for one school. (b) Student flow for one school. [Colour online.]

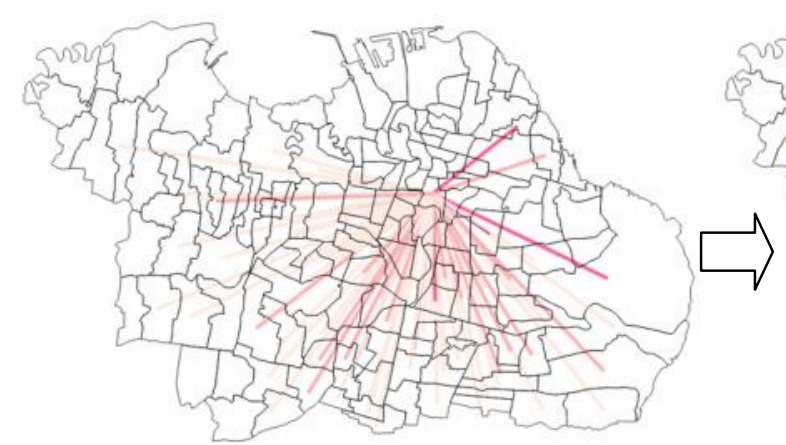

(a)

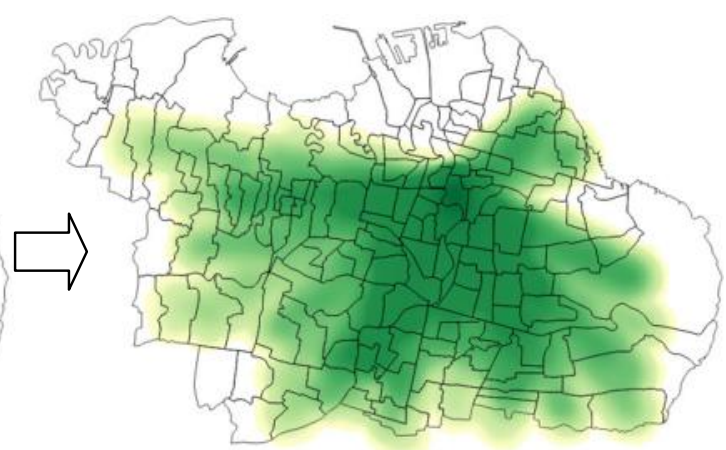

(b)

Figure 8. Student flow factor. [Colour online.]

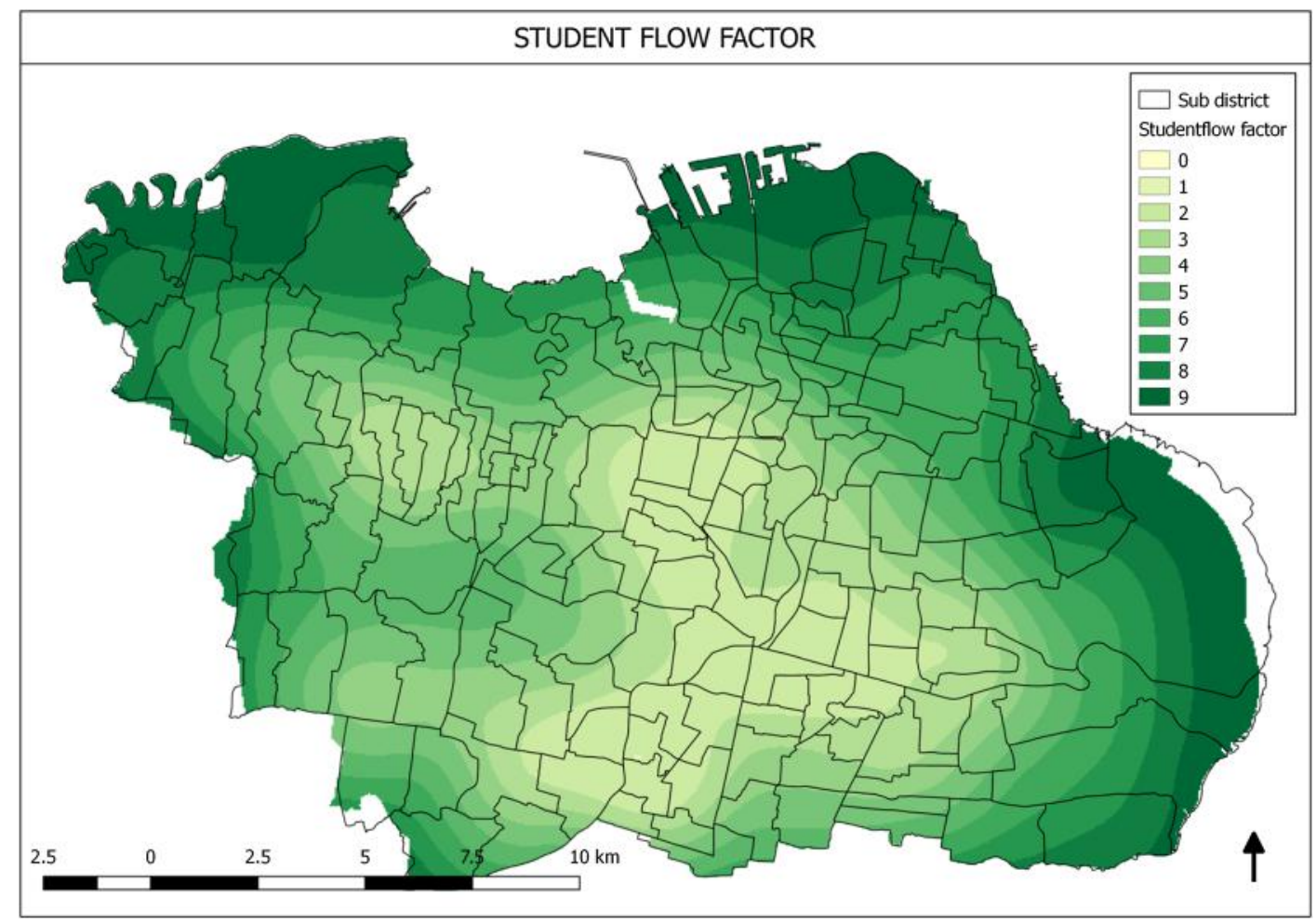

- the sub-districts where their residences were located

- students' opinion on the importance to consider the distance between their residence and the school

- the maximum distance that was still accepted if such a distance was perceived to be important

- the sub-districts where they work

- the importance of the distance between the workplace and the targeted school

- the maximum distance that was still accepted if the distance between workplace and school was perceived to be important 
Figure 9. (a) Buffer of "near house", "near workplace”, and "near house-to-workplace" of two data samples filled by random points. (b) Preferred school areas of two data samples. [Colour online.]

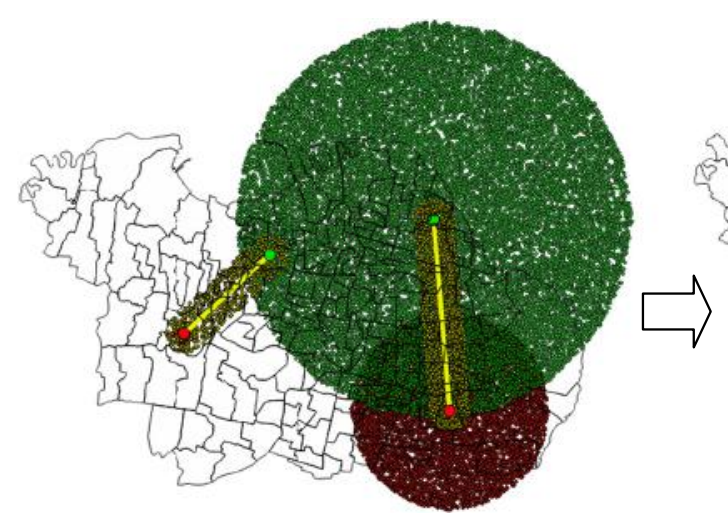

(a)

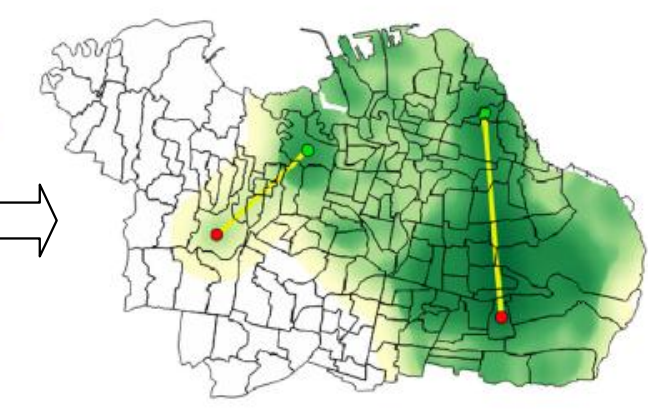

(b)

- opinions regarding whether it was acceptable or not to build a school around the way from home to workplace

- the acceptance level of the home to workplace area.

The spatial process could be illustrated from two respondents whose parents worked in different regions (east and west), while the family lived in the northern region. In addition to having different work sites, the first parent accepted an area near his or her house and a workplace that was small, whereas the second parent preferred a larger workspace. However, the second parent accepted a distance that was approximately $10 \mathrm{~km}$ from his house and approximately $5 \mathrm{~km}$ from his workplace. Therefore, two buffers of "near house", two buffers of "near workplace", and two buffers of "house to workplace line" were generated. The next step was converting the buffer area into a raster format that indicated the acceptability level of planned school location. The area that was included in more buffers had a higher acceptability level. This calculation needed a heat map analyst function. Random points inside the polygon function would be reused. The number of points had to correspond with the buffer area and the importance level (based on the distance of house to school, workplace to school, and home to workplace). A region in two buffer areas received additional object points. As a result, the area had more heat map sources. Figure $9 a$ shows these generated random points.

The next process was running the heat map function and reclassifying the result. Figure $9 b$ shows the heat map followed by the reclassification result. These steps were applied into 1854 rows of data collected from respondents using the web-GIS application. The final result was the public preference factor, as shown in Fig. 10.

The six factors have different characteristics. The administration factor and student flow factor insist that new schools be built in the outer area of the city. The population factor, the transportation factor, and the public preferences factor suggest that new schools be built in the inner area of the city. Each factor was weighted during the MCDA process. We used the AHP and F-AHP methods to determine the weight of each factor and conducted surveys not only of the city government, but also city planning experts. This study used a web-GIS application to collect judgment. The user had to compare each pairwise factor and decide whether a factor is "less important", "important", "more important", "much more important", or "the same importance" compared with another factor. The user can view their judgment result map and review their pairwise comparison. 
Figure 10. Public preferences factor. [Colour online.]

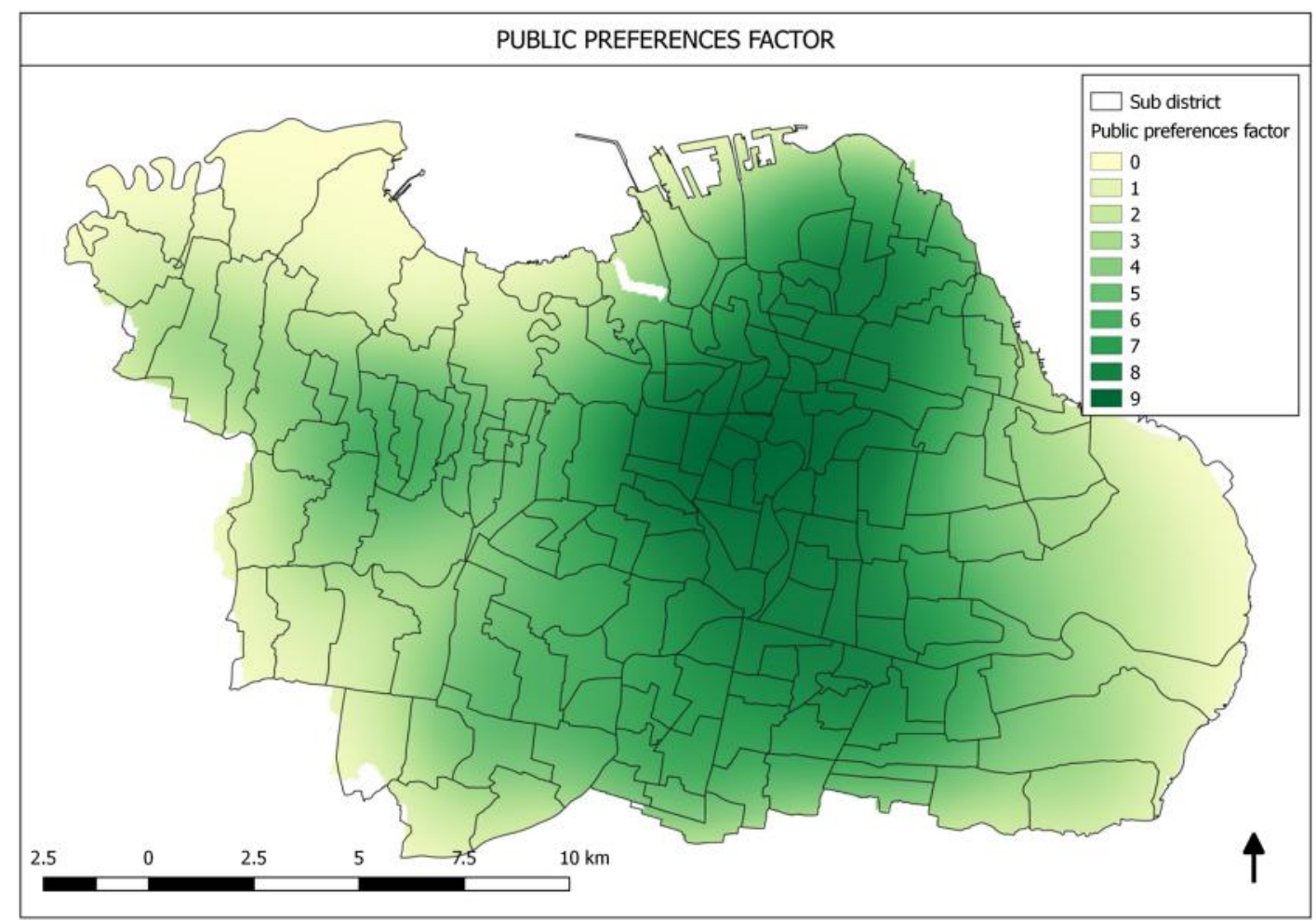

\section{Results and Discussion}

The research subject involved two departments in Surabaya: the Department of Education and the Department of City Planning and Development. Therefore, the key respondents are the head of these departments and their subordinates who are concerned with this subject. Other respondents were professionals and scientists in the city planning field. Each respondent had to provide a justification.

We used the traditional AHP and F-AHP methods with scale points such as those shown in Table 1.

Using the traditional AHP method, we proceeded with the respondent pairwise judgement independently and combined each respondent weight result with the geometric mean method to obtain the composite weight. This composite weight was then normalized to obtain the final weight (W'). Table 2 shows the AHP result of each respondent. Respondents 1-4 were from the government, respondents 5-8 were from experts, and respondents 1 and 2 were from the Department of Education. These respondents indicated the three most important factors were administration, population, and transportation. However, respondents 3 and 4, who were from the Departement of City Planning and Development, stated that the most important factors were population, public preferences, and land allocation. The judgments from the experts were more random than those from the government.

Using the F-AHP method, all respondent pairwise judgments were simultaneously processed. The averages of each pairwise judgement triangular point were calculated (Chang). These averages were then combined using the geometric mean method. The next step was to identify the vector summation of the geometric mean result. All geometric mean factors were summed. The results were then reversed and re-ordered, because to obtain the $\mathbf{r}^{\prime}$ 
Table 1. AHP scale and fuzzy triangular scale.

\begin{tabular}{lllll}
\hline & & & \multicolumn{2}{l}{ Reverse } \\
\cline { 4 - 5 } Definition & AHP scale & F-AHP scale & AHP & F-AHP \\
\hline Equally important & 1 & $(1,1,1)$ & 1 & $(1,1,1)$ \\
Weakly important & 3 & $(2,3,4)$ & 0.33 & $(0.5,0.33,0.25)$ \\
Fairly important & 5 & $(4,5,6)$ & 0.2 & $(0.25,0.2,0.167)$ \\
Strongly important & 7 & $(6,7,8)$ & 0.143 & $(0.167,0.143,0.125)$ \\
Absolutely important & 9 & $(9,9,9)$ & 0.111 & $(0.111,0.111,0.111)$ \\
\hline
\end{tabular}

Table 2. AHP results.

\begin{tabular}{lllllllllll}
\hline & \multicolumn{3}{l}{ Respondent } \\
\cline { 2 - 8 } Factor & 1 & 2 & 3 & 4 & 5 & 6 & 7 & 8 & \multirow{2}{*}{ Geomean } & $W^{\prime}$ \\
\hline Administration & 0.491 & 0.245 & 0.078 & 0.103 & 0.055 & 0.092 & 0.450 & 0.046 & 0.133 & 0.195 \\
Population & 0.213 & 0.472 & 0.449 & 0.233 & 0.253 & 0.224 & 0.041 & 0.123 & 0.204 & 0.298 \\
Transportation & 0.162 & 0.102 & 0.041 & 0.028 & 0.445 & 0.031 & 0.024 & 0.453 & 0.085 & 0.125 \\
Land allocation & 0.024 & 0.068 & 0.141 & 0.154 & 0.157 & 0.155 & 0.159 & 0.042 & 0.093 & 0.136 \\
Student flow & 0.042 & 0.084 & 0.025 & 0.030 & 0.065 & 0.034 & 0.257 & 0.280 & 0.067 & 0.098 \\
Public Preferences & 0.068 & 0.030 & 0.265 & 0.452 & 0.025 & 0.465 & 0.069 & 0.057 & 0.101 & 0.148 \\
\hline
\end{tabular}

Table 3. F-AHP calculation and results.

\begin{tabular}{|c|c|c|c|c|c|c|c|c|}
\hline \multirow{2}{*}{ Factor } & \multicolumn{3}{|c|}{ Geomean } & \multicolumn{3}{|c|}{$\begin{array}{l}\text { Relative fuzzy weight } \\
\left(\text { Geomean } \times \mathrm{r}^{\prime}\right)\end{array}$} & \multirow[t]{2}{*}{ W } & \multirow[t]{2}{*}{$W^{\prime}$} \\
\hline & & & & & & & & \\
\hline Administration & 2.395 & 2.668 & 2.946 & 0.150 & 0.188 & 0.234 & 0.191 & 0.187 \\
\hline Population & 3.039 & 3.412 & 3.842 & 0.191 & 0.240 & 0.306 & 0.246 & 0.241 \\
\hline Transportation & 1.995 & 2.199 & 2.396 & 0.125 & 0.155 & 0.191 & 0.157 & 0.154 \\
\hline Land allocation & 1.600 & 1.906 & 2.222 & 0.100 & 0.134 & 0.177 & 0.137 & 0.135 \\
\hline Student flow & 1.489 & 1.689 & 1.891 & 0.093 & 0.119 & 0.150 & 0.121 & 0.119 \\
\hline Public preferences & 2.049 & 2.320 & 2.641 & 0.129 & 0.163 & 0.210 & 0.167 & 0.164 \\
\hline Total & 12.568 & 14.194 & 15.939 & - & - & - & - & - \\
\hline Reverse $(r)$ & 0.080 & 0.070 & 0.063 & - & - & - & - & - \\
\hline Increasing order $\left(r^{\prime}\right)$ & 0.063 & 0.070 & 0.080 & - & - & - & - & - \\
\hline
\end{tabular}

number, the numbers in the fuzzy triangle must be ordered from lowest to highest. The relative fuzzy weight was the multiplication of $\mathrm{r}^{\prime}$ and the geometric mean of the judgements. This weight was also in a triangular number format and needed to be converted to a single number to obtain the factor weight. This triangular number was averaged and normalized to obtain the final weight. Table 3 shows this calculation.

The AHP and F-AHP methods showed a slightly different result. Both the AHP and F-AHP methods indicated population to be the most important factor, followed by administration, public preference, and land allocation. Although the AHP method showed that the fourth most important factor was transportation, the F-AHP method indicated that land allocation was the fourth most important factor. Lastly, these two methods indicated that student flow was the weakest factor. Figure 11 graphically shows this comparison result.

The final SMCDA process combined all factors, which were already in a raster format, with different weights taken from the AHP or F-AHP calculations. The F-AHP obtained the following formula:

Suitability level $=(0.187 \times$ administration factor $)+(0.241 \times$ population factor $)$

$$
\begin{aligned}
& +(0.154 \times \text { transportation factor })+(0.135 \times \text { land Allocation factor }) \\
& +(0.119 \times \text { student flow factor })+(0.102 \times \text { public preference factor })
\end{aligned}
$$


Figure 11. Comparison of AHP and F-AHP results. Factor abbreviations are as follows: adm, administration; popul, population; Trans, transportation; Land alloc, land allocation; Flow, student flow; Pref, public preferences. [Colour online.]

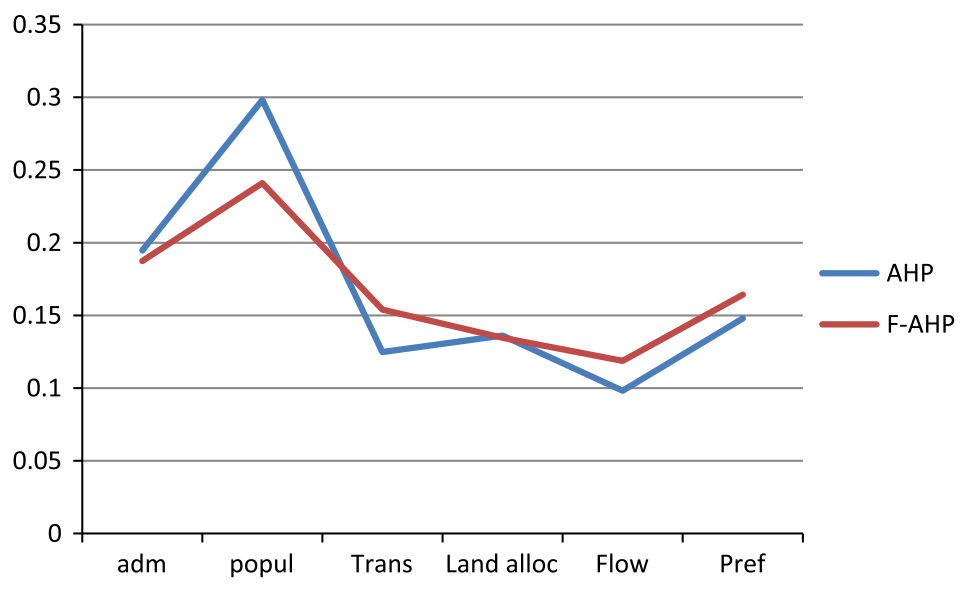

Figure 12. SMCDA result map: suitability level map. [Colour online.]

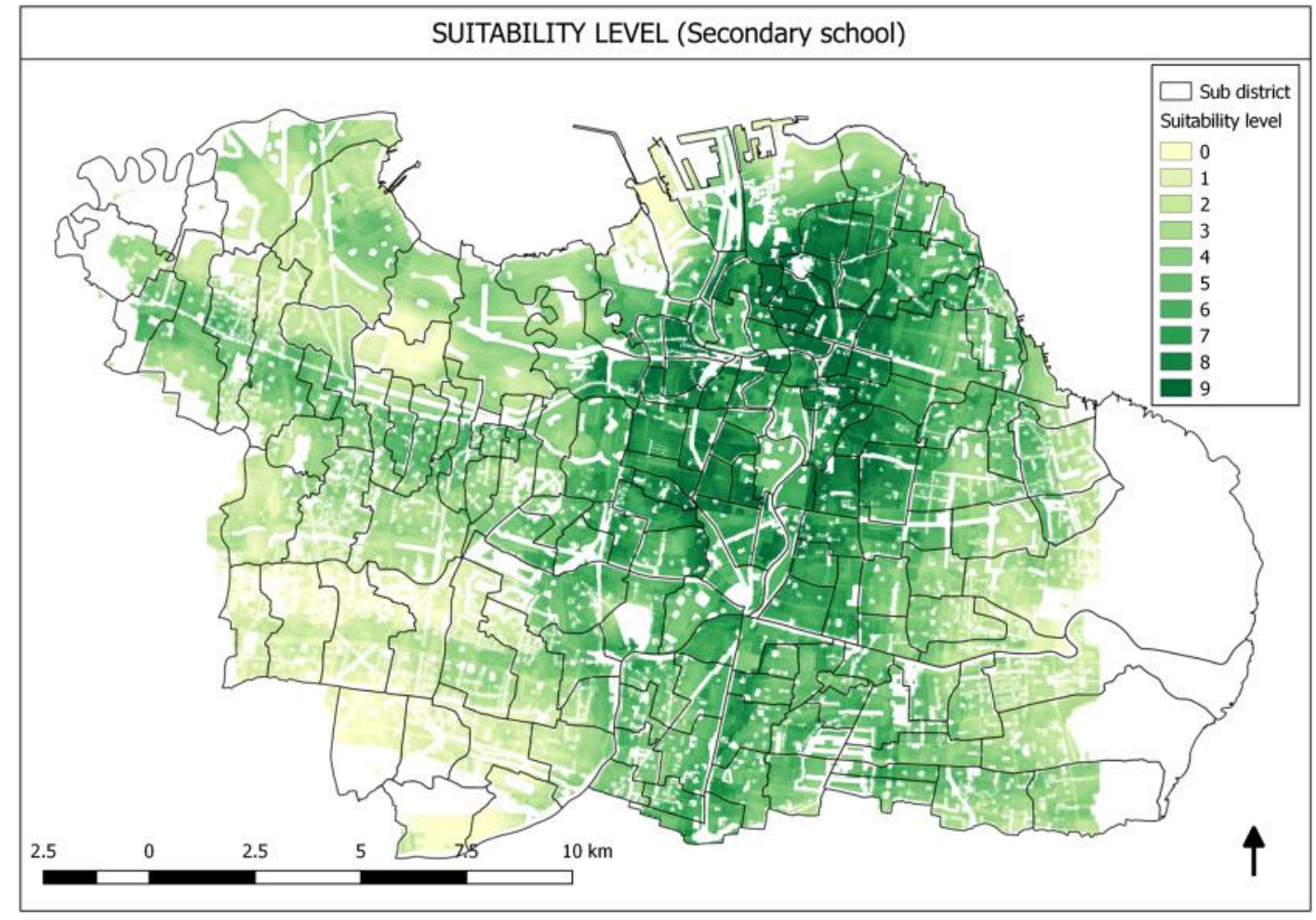

This formula was applied in the raster calculation and continued with the reclassification process to obtain the final suitability level map. The use of AHP weight or F-AHP weight resulted in only a slighly different raster map in the area within the intermediate level. The 
high and the low suitability level area show very little difference. Figure 12 shows the suitability level map for secondary schools.

The yellow and green gradations in Fig. 12 show the suitability level of a location to establish a new school. The darker the colour, the more suitable the area would be and vice versa. From this map, we can conclude that although the city center already had a number of schools, it still needed additional schools because it had a high population density, complete with good public transportation facilities.

\section{Conclusion}

This research proposed a method to discover the preferences of areas to establish new schools by involving six influential factors: administration, population, transportation, land allocation, student flow, and public preferences. The raw data used to produce these factors included citizen and student databases, a map of school locations, public transportation routes, administration, and land allocation.

One of those factors was produced using a PPGIS application. The factors were combined using SMCDA that integrated opinions from decision makers andexperts. Another PPGIS application was used to obtain the pairwise judgment. The population, public preference, and transportation factors suggested that the development be in the city center, whereas the administration and student flow factors prohibited this area. The land allocation factor suggested the development be in a more specific area. The web-GIS MCDA proved that these factors can be compromised. Although the non-GIS-based MCDA had only several alternatives, the GIS-based MCDA could create abundant alternatives. For example, when a school needed an area of $100 \mathrm{~m} \times 100 \mathrm{~m}$, the application will show 3.330 alternatives because the area of Surabaya is $33306 \mathrm{~km}^{2}$. If there are two factors opposite each other, the nonGIS-based MCDA may take the optimal alternatives, e.g., the average value of those two factors. In GIS-based MCDA, the chance to obtain an alternative with a higher value is higher.

All factors were built based on last 3 years of primary data. The static development, administrative area, public transportation facilities, and land allocation planning were predicted not to change much during the next 10-15 years. The total number of school-age citizens was already forecasted for 20 years. Changes in student flow and public preferences were not predicted during this research. The pattern of students' routes and public preferences on school location might change in a few years. These are limitations of the current research and it should be refined in a further study.

The final result of this research could clearly determine the suitability of some areas in Surabaya for additional schools. It then could be sent to the government to support their consideration to build new schools or remove unfulfilled primary schools. The proposed method in this study included two PPGIS applications: the application to collect the data on public preferences and the application to obtain and calculate the pairwise judgment process, and it can be adopted in other cities in Indonesia using their own databases and maps. Lastly, this proposed method can be taken as a reference by other cities to develop and process their own data.

\section{References}

Abudeif, A.M., Abdel Moneim, A.A., and Farrag, A.F. 2015. Multicriteria decision analysis based on analytic hierarchy process in GIS environment for siting nuclear power plant in Egypt. Ann. Nucl. Energy, 75: 682-692. doi:10.1016/j.anucene.2014.09.024.

Aksoy, E., and San, B.T. 2017. Geographical information systems (GIS) and multi-criteria decision analysis (MCDA) integration for sustainable landfill site selection considering dynamic data source. Bull. Eng. Geol. Environ. 1-13. doi:10.1007/s10064-017-1135-z.

Aly, A., Jensen, S.S., and Pedersen, A.B. 2017. Solar power potential of Tanzania: identifying CSP and PV hot spots through a GIS multicriteria decision making analysis. Renewable Energy, 113: 159-175. doi:10.1016/j. renene.2017.05.077. 
Anwarzai, M.A., and Nagasaka, K. 2017. Utility-scale implementable potential of wind and solar energies for Afghanistan using GIS multi-criteria decision analysis. Renewable Sustainable Energy Rev. 71: 150-160. doi:10.1016/j.rser.2016.12.048.

Atici, K.B., Simsek, A.B., Ulucan, A., and Tosun, M.U. 2015. A GIS-based multiple criteria decision analysis approach for wind power plant site selection. Utilities Policy, 37: 86-96. doi:10.1016/j.jup.2015.06.001.

Ayhan, M.B. 2013. A fuzzy AHP approach for supplier selection problem: a case study in a Gearmotor Company. Int. J. Managing Value Supply Chains, 4: 11-23. doi:10.5121/ijmvsc.2013.4302.

Bagaram, B.M., Mounir, F., Lahssini, S., and Ponette, Q. 2016. Site suitability analysis for cork oak regeneration using GIS-based multicriteria evaluation techniques in Maamora Forest-Morocco. OALib, 3: 1-9. doi:10.4236/ oalib.1102483.

Bozdağ, A., Yavuz, F., and Günay, A.S. 2016. AHP and GIS based land suitability analysis for Cihanbeyli Turkey County. Environ. Earth Sci. 75: 813. doi:10.1007/s12665-016-5558-9.

Demesouka, O.E., Vavatsikos, A.P., and Anagnostopoulos, K.P. 2016. Using MACBETH multicriteria technique for GIS-based landfill suitability analysis. J. Environ. Eng. 142: 04016042. doi:10.1061/(ASCE)EE.1943-7870.0001109.

Dragićević, S., Lai, T., and Balram, S. 2015. GIS-based multi-criteria evaluation with multi-scale analysis to characterize urban landslide susceptibility in data-scarce environments. Habitat Int. 45: 114-125. doi:10.1016/j. habitatint.2014.06.031.

Erener, A., Mutlu, A., and Sebnem Düzgün, H. 2016. A comparative study for landslide susceptibility mapping using GIS-based multi-criteria decision analysis MCDA, logistic regression LR and association rule mining ARM. Eng. Geol. 203: 45-55. doi:10.1016/j.enggeo.2015.09.007.

Esquivel, J.M., Morales, G.P., and Esteller, M.V. 2015. Groundwater monitoring network design using GIS and multicriteria analysis. Water Resour. Manage. 29: 3175-3194. doi:10.1007/s11269-015-0989-8.

Grêt-Regamey, A., Altwegg, J., Sirén, E.A., van Strien, M.J., and Weibel, B. 2017. Integrating ecosystem services into spatial planning-A spatial decision support tool. Landscape Urban Plann. 165: 206-219. doi:10.1016/j. landurbplan.2016.05.003.

Jelokhani-Niaraki, M., and Malczewski, J. 2015. Decision complexity and consensus in web-based spatial decision making: a case study of site selection problem using GIS and multi-criteria analysis. Cities, 45: 60-70. doi:10.1016/j.cities.2015.03.007.

Jiménez Capilla, J.A., Carrión, J.A., and Alameda-Hernandez, E. 2016. Optimal site selection for upper reservoirs in pump-back systems, using geographical information systems and multi-criteria analysis. Renewable Energy, 86: 429-440. doi:10.1016/j.renene.2015.08.035.

Latinopoulos, D., and Kechagia, K. 2015. A GIS-based multi-criteria evaluation for wind farm site selection. A regional scale application in Greece. Renewable Energy, 78: 550-560. doi:10.1016/j.renene.2015.01.041.

Mosadeghi, R., Warnken, J., Tomlinson, R., and Mirfenderesk, H. 2015. Comparison of fuzzy-AHP and AHP in a spatial multi-criteria decision making model for urban land-use planning. Comp. Environ. Urban Syst. 49: 54-65. doi:10.1016/j.compenvurbsys.2014.10.001.

Nguyen, T.T., Verdoodt, A., Tran, V.Y., Delbecque, N., Tran, T.C., and Van Ranst, E. 2015. Design of a GIS and multicriteria based land evaluation procedure for sustainable land-use planning at the regional level. Agric. Ecosyst. Environ. 200: 1-11. doi:10.1016/j.agee.2014.10.015.

Noorollahi, Y., Yousefi, H., and Mohammadi, M. 2016. Multi-criteria decision support system for wind farm site selection using GIS. Sustain. Energy Technol. Assess. 13: 38-50. doi:10.1016/j.seta.2015.11.007.

Nzeyimana, I., Hartemink, A.E., and Geissen, V. 2014. GIS-based multi-criteria analysis for Arabica coffee expansion in Rwanda. PLoS ONE, 9: e107449. doi:10.1371/journal.pone.0107449. PMID:25299459.

Papaioannou, G., Vasiliades, L., and Loukas, A. 2015. Multi-criteria analysis framework for potential flood prone areas mapping. Water Resour. Manage. 29: 399-418. doi:10.1007/s11269-014-0817-6.

Pourghasemi, H.R., Moradi, H.R., Fatemi Aghda, S.M., Gokceoglu, C., and Pradhan, B. 2014. GIS-based landslide susceptibility mapping with probabilistic likelihood ratio and spatial multi-criteria evaluation models North of Tehran, Iran. Arabian J. Geosci. 7: 1857-1878. doi:10.1007/s12517-012-0825-X.

Prasetyo, D.H., Muhamad, J., and Fauzi, R. 2016a. Development of online spatial multi-criteria decision analyst application: case study on determining area suitability for school location in Surabaya, Indonesia. IOP Conf. Ser.: Earth Environ. Sci. 37: 012051. doi:10.1088/1755-1315/37/1/012051.

Prasetyo, D.H., Mohamad, J., and Fauzi, R. 2016b. Discovering public preferences for school location in Surabaya. Procedia - Social Behav. Sci. 227: 160-167. doi:10.1016/j.sbspro.2016.06.057.

Rahmati, O., Zeinivand, H., and Besharat, M. 2016. Flood hazard Zoning in Yasooj region, Iran, using GIS and multicriteria decision analysis. Geomatics, Natural Hazards Risk, 7: 1000-1017. doi:10.1080/19475705.2015.1045043.

Rikalovic, A., Cosic, I., and Lazarevic, D. 2014. GIS based multi-criteria analysis for industrial site selection. Procedia Eng. 69: 1054-1063. doi:10.1016/j.proeng.2014.03.090.

Romano, G., Dal Sasso, P., Trisorio Liuzzi, G., and Gentile, F. 2015. Multi-criteria decision analysis for land suitability mapping in a rural area of Southern Italy. Land Use Policy, 48: 131-143. doi:10.1016/j.landusepol.2015.05.013.

Saaty, T.L., and Shang, J.S. 2007. Group decision-making: head-count versus intensity of preference. Socio-Econ. Plann. Sci. 41: 22-37. doi:10.1016/j.seps.2005.10.001.

Sahoo, S., Jha, M.K., Kumar, N., and Chowdary, V.M. 2015. Evaluation of GIS-based multi-criteria decision analysis and probabilistic modeling for exploring groundwater prospects. Environ. Earth Sci. 74: 2223-2246. doi:10.1007| s12665-015-4213-1. 
Saidi, S., Hosni, S., Mannai, H., Jelassi, F., Bouri, S., and Anselme, B. 2017. GIS-based multi-criteria analysis and vulnerability method for the potential groundwater recharge delineation, case study of Manouba phreatic aquifer, NE Tunisia. Environ. Earth Sci. 76: 511. doi:10.1007/s12665-017-6840-1.

Shokati, B., Asgharipour, M.R., Ghanbari, A., and Feizizadeh, B. 2016. Suitability assessment of saffron cultivation using GIS based multi-criteria decision analysis approach; study area: East-Azerbaijan province. Desert, 21: 115-131. doi:10.22059/jdesert.2016.60327.

Siefi, S., Karimi, H., Soffianian, A.R., and Pourmanafi, S. 2017. GIS-based multi criteria evaluation for thermal power plant site selection in Kahnuj County, SE Iran. Civil Eng. Infrastruct. J. 50: 179-189. doi:10.7508/ceij.2017.01.011.

Singh, C.K., and Katpatal, Y.B. 2017. A GIS based design of groundwater level monitoring network using multicriteria analysis and geostatistical method. Water Resourc. Manage. 31: 4149-4163. doi:10.1007/s11269-017-1737-z.

Srichetta, P., and Thurachon, W. 2012. Applying fuzzy analytic hierarchy process to evaluate and select product of notebook computers. Int. J. Model. Optimization, 168-173. doi:10.7763/IJMO.2012.V2.105.

Szurek, M., Blachowski, J., and Nowacka, A. 2014. GIS-based method for wind farm location multi-criteria analysis. 21: $65-81$. doi: $10.5277 / \mathrm{ms} 142106$.

Vasileiou, M., Loukogeorgaki, E., and Vagiona, D.G. 2017. GIS-based multi-criteria decision analysis for site selection of hybrid offshore wind and wave energy systems in Greece. Renewable Sustainable Energy Rev. 73: 745-757. doi:10.1016/j.rser.2017.01.161.

Veronesi, F., Schito, J., Grassi, S., and Raubal, M. 2017. Automatic selection of weights for GIS-based multicriteria decision analysis: site selection of transmission towers as a case study. Appl. Geogr. 83: 78-85. doi:10.1016/j. apgeog.2017.04.001.

Watson, J.J.W., and Hudson, M.D. 2015. Regional scale wind farm and solar farm suitability assessment using GIS-assisted multi-criteria evaluation. Landscape Urban Plann. 138: 20-31. doi:10.1016/j.landurbplan.2015.02.001.

Yalew, S.G., van Griensven, A., and van der Zaag, P. 2016. AgriSuit: a web-based GIS-MCDA framework for agricultural land suitability assessment. Comput. Electron. Agric. 128: 1-8. doi:10.1016/j.compag.2016.08.008. 